\title{
An Introduction to the Person-Centred Approach as an Attitude for Participatory Design
}

\section{Sarah Kettley}

Nottingham Trent University

Nottingham, NG1 4BU, UK

sarah.kettley@ntu.ac.uk

\section{Richard Kettley}

Nottingham Trent University

Nottingham, NG1 4BU, UK

richard.kettley@ntu.ac.uk

\section{Matthew Bates}

Nottingham Trent University

Nottingham, NG1 4BU, UK

matthew.bates@ntu.ac.uk

Permission to make digital or hard copies of all or part of this work for personal or classroom use is granted without fee provided that copies are personal or classrom use is granted without fee provided that copies a not made or distributed for profit or coming copies bear this notice and the full citation on the first page. Copyrights for components of this work owned by others than ACM must be honored. Abstracting with credit is permitted. To copy otherwise, or republish, to post on servers or to redistribute to lists, requires prior specific permission and/or a fee. Request permissions from

Permissions@acm.org. Ubicomp/ISWC'15 Adjunct, September 07-11, 2015, Osaka, Japan (c) 2015 ACM. ISBN 978-1-4503-3575

1/15/09...\$15.00 DOI: http://dx.doi.org/10.1145/2800835.2807945

\begin{abstract}
This paper is one of three talks which reflect on the use of participatory design methods, especially in the context of design for mental health and wellbeing. In them we: introduce the Person-Centred Approach as a framework for conducting Participatory Design; outline the method of Interpersonal Process Recall (IPR); and present a heuristic case study of these approaches being developed by a multidisciplinary design research team with Mind, a UK mental health charity. In this paper, we introduce the Person-Centred Approach (PCA) as found in psychotherapy, education and conciliation processes. We propose that this approach can help the field of Participatory Design recognise that researchers and research teams constructively inform their practice through the attitudes they bring to what is necessarily a relational situation. The PCA will be of interest to researchers working with mental health and wellbeing communities in particular, but may also be valuable in offering a framework for Participatory Design as a broad field of practice. The paper describes different modes of practice to be found in

psychotherapy and outlines key aspects of the PCA, before discussing its implications for doing Participatory Design.
\end{abstract}




\section{Author Keywords}

Attitude; Participatory Design; team working; wellbeing; phenomenological methods; ethics.

\section{ACM Classification Keywords}

J.4 [Social And Behavioral Sciences]: Psychology; K.4.1 [Public Policy Issues]: Ethics.

\section{Introduction}

The Person-Centred Approach [9] differs in many respects to other psychological modalities. It is humanistic in outlook with its roots in phenomenological and existential philosophy and practice. Carl Rogers developed the approach from Non-Directive Therapy to Client-Centred Therapy to Person-Centred Therapy through the 1940 s to 1960 s, and then to the broader Person-Centred Approach which influenced educational, sociological and political theory and practice from the 1970s onwards [2]. Its emphasis is on trust in the individual to grow and develop given the right environment [4]. It is at odds with a medical approach to mental health, which is disease- and deficit- based [3]

In terms of our research project, we seek to champion the Person-Centred Approach through: power dynamics, a holistic outlook, movement, the experiential nature of the approach, the research methodology and methods, the therapeutic benefits of research participation, self-respect, and good practice according to the British Association of Counselling Professional (BACP) guidelines. We outline each of these dimensions in the sections that follow.

\section{Power dynamics}

We intend co-researchers to experience empathic attitudes and unconditional positive regard [7] from researchers, so that they feel heard and valued. This is a qualitative approach to research which embraces richness and diversity, even where this leads to ambiguous or even contradictory findings. Researchers display a willingness to communicate their own presence in the research relationship, along with a commitment to exploring their own self-awareness and to be transparent in what they are doing.

\section{Holistic outlook}

We start from the position that experience is based on all that is available to awareness and that this will be different for different people. Therefore we aim to offer various ways of inviting reflection on cognitive, psychological, emotional, physiological, and behavioural experiences. Our relational attitude aims to be empathic and non-judgemental.

We aim to nurture in co-researchers their 'organismic valuing process' [6], meaning we value what is truly important to them, not to society's or any expert's view of how they should be. This may be achieved by seeking to co-create a safe environment with clear, negotiated boundaries, which are reflected upon and re-evaluated against new experience.

\section{Movement}

Our model of the person is essentially dynamic [8]. Feeling stuck and/or having a rigid outlook may be symptomatic of distress or fear of judgement and disapproval; whereas openness and flexibility are seen as signs of self-confidence and resilience. Change may 
occur in moments or over time, and can be the result of relational depth [5].

\section{Experiential approach}

We aim to offer co-researchers open-ended contexts and frameworks where they are free to self-direct and to create the content. As researchers we seek to both explore this content in the spirit of phenomenological inquiry, and to co-create meanings with a respect for the autonomy of the co-researchers.

\section{Research methodology and methods}

The Person-Centred Approach to research "is characterised by a developing rather than a pretheorised mode of inquiry" [10:123].

We acknowledge that others in the multidisciplinary team have different experience and outlooks and we may have to explore the tensions between:

- Human science / Natural science

- Qualitative / Quantitative

- Subjectivity / Objectivity

- Process / Outcome

In considering, planning and implementing methodology, we aim to prioritise approaches that value openness, inclusivity, and tolerance of difference and ambiguity.

We try to build in invitations for evaluation by coresearchers as well as researchers, and to value all responses. Where possible, we seek to acknowledge a distinction between an internal 'locus of evaluation' [6] - how individuals truly feel - and an external locus where individuals feel obliged to respond in a certain way because of their perception of society's expectations. Again the relationship between researchers and co-researchers is important here - we hope it will be based on openness and trustworthiness.

\section{Therapeutic benefits of research}

\section{participation}

We anticipate the possibility of improved experience of wellbeing:

- Practical benefits as a result of describing or reflecting on research participation as part of a group, such as ability to stay in the room, to share thoughts and feelings with others, to develop support networks

- Creative benefits in self-expression and feelings of achievement

- Meaning-making in being able to explore and discover

We accept that different people may experience such benefits in different ways: cognitively, psychologically, emotionally, physiologically and/or behaviourally.

\section{Self respect}

It is critical that as researchers we recognise the importance of self-care. This might mean having the opportunity to process difficult thoughts and feelings in self-reflection or with others. Or it might mean taking a break from the stress and strain of intense work, and knowing what feels good - fresh air, food/drink, activity, music etc.

We also need to become aware of our limitations. This might be in terms of our role within the research team or in relationship with co-researchers. 
There can be a risk of vicarious trauma in working with mental health. It is important to know who or what our support systems are.

\section{Good practice}

The BACP Ethical Guidelines for Research [1] offers a way of working ethically in this field that takes account of:

- Trustworthiness

- Managing risks

- Relationships with participants

- Integrity

- Governance

- Research culture

- Relationships with colleagues

- Responsibilities to self

\section{An Internet of Soft Things}

Following Phase One (of four) of the project we already know that many in the mental health community do not use smart phones or online technology. We also know that soft textiles are appealing from a sensory and experiential point of view, and that self-made objects hold significant meanings for people.

In the next phase of the project we are developing a storyboarding tool to help people think about and codesign different possible connections between things (the ' ${ }^{\prime} \mathrm{T}^{\prime}$ '), and to explore the implications of sharing information with others and/or having others share information with you.

\section{Acknowledgements}

We thank all the participants who took part in our pilot study in Nottingham in 2014, and the Bassetlaw Mind service users, staff and volunteers who contributed to the participatory design workshops in 2015. This work has been made possible through an EPSRC Researchin-the-Wild grant EP/L023601/1.

\section{References}

[1] BACP Ethical Guidelines for Researching Counselling and Psychotherapy.

http://www.bacp.co.uk/research/ethical_guidelines.php

[2] Embleton-Tudor, L., Keemar K., Tudor, K.,

Valentine, J. and Worrall, M. The Person-Centred Approach: A Contemporary Introduction. Palgrave Macmillan, Basingstoke, 2004.

[3] Freeth, R. Humanising Psychiatry and Mental Health Care: The Challenge of the Person-Centred Approach. Routledge, London, 2007.

[4] Joseph, S. and Worsley, R. (Eds.). Person-Centred Psychopathology: A Positive psychology of Mental Health. PCCS Books, Ross-on-Wye, 2005.

[5] Mearns, D. and Cooper, M. Working at Relational Depth in Counselling and Psychotherapy. Sage, London, 2005.

[6] Mearns, D. and Thorne, B. Person-Centred Counselling In Action ( $3^{\text {rd }}$ ed). Sage, London, 2007.

[7] Rogers, C. R. The Necessary and Sufficient

Conditions of Therapeutic Personality Change (1957).

In $\mathrm{H}$. Kirschenbaum and V. L. Henderson (Eds.). The Carl Rogers Reader. Constable, London, 1990, 219235.

[8] Rogers, C. R. On Becoming A Person. Constable, London, 1961.

[9] Sanders, P. (Ed.). The Tribes of the Person-Centred Approach: An Introduction to the Schools of Therapy Related to the Person-Centred Approach. PCCS Books, Ross-on-Wye, 2004.

[10] Tudor, K. and Merry, T. Dictionary of Person-

Centred Psychology. PCCS Books, Ross-on-Wye, 2002. 